\title{
"A Modern Financial Tool-kit": Lessons from Adolf A. Berle for a More Democratic Financial System
}

\author{
Authors: ${ }^{1} \quad$ Sarah Quinn, University of Washington ${ }^{1}$ \\ Mark Igra, University of Washington \\ Selen Güler, University of Washington
}

\begin{abstract}
:
At the close of the 1930s, Adolf Berle - brain truster and co-author of The Modern Corporation and Private Property - developed a plan for a "modern financial tool-kit." This paper recovers Berle's program for financial reform. The discussion opens with an overview of Berle's personal and intellectual history, the historical moment in which he developed these proposals, and a summary of alternative proposals circulating at the time. Berle's own proposals are then presented. Notably, we find that Berle stresses the need for (quasi-)public banks, improved infrastructure finance, and loan guarantees for small business. Based on these proposals, we draw three lessons for efforts to democratize finance today. The first concerns the importance of critiquing misguided alternatives. Here we assert that proponents of democratized finance should push back against private equity's encroachment on public infrastructure. The second lesson takes inspiration from Berle' invocation of precedents for government action as justifications for further reform. Here we argue for a closer focus on the trillions in loans currently owned or guaranteed via federal credit programs. The third lesson takes inspiration from Berle's articulation of core principles to guide reform. In that tradition, we offer a distillation of the overarching principles of Berle that might guide democratic financial reform today: fair allocation, local and global sustainability, and political accountability.
\end{abstract}

\footnotetext{
${ }^{1}$ This paper was written as a chapter for the upcoming volume Democratizing Finance, edited by Fred Block and Bob Hockett, as part of the Real Utopia Series. For correspondence, please contact Sarah Quinn (slquinn@uw.edu).
} 
"The Wall Street banking system is doing exactly what one would expect it to do

- no less and no more. If anything real is to be accomplished along these lines, the foundation has to be laid for a capital credit system that really works."

- Adolf A. Berle Jr., 1938

Adolf A. Berle Jr. was one of the $20^{\text {th }}$ century's great theorists of corporate power and democratic accountability. At the close of the 1930s, he circulated two memoranda that asked readers to rethink the national allocation of long-term credit. The memoranda culminated in a proposal for a "modern financial tool-kit" made up of (1) a Public Works Finance Corporation, (2) loan guarantees for small businesses, and (3) a new "banking system for capital and credit" to be developed by a government committee. Berle's memos provide few details about how these ideas should actually be designed and implemented, but they do elaborate on the necessity of bold reform. Berle rejected the idea that banking necessarily had to be a for-profit enterprise. On the contrary, because public institutions made banking and credit possible, banks should pursue the public good, not private profit.

This chapter recovers Berle's program for banking reforms and puts that plan in conversation with current work. To establish the importance of focusing on Berle's plans, and to provide useful context for understanding his arguments and goals, the paper opens with a brief biography of Berle and a refresher on The Modern Corporation and Private Property, his classic book co-written with Gardiner Means. This is followed by an overview of the immediate context in which Berle writes about banking reform, which includes an overview of other proposals for banking reform that proliferated during the late New Deal. These other proposals informed 
Berle's work, and Berle's work can be read as one expression of these more general debates. We then present summaries of his proposals - two memoranda prepared in 1938 and 1939 for members of the Temporary National Economic Committee (TNEC).

The paper ends with a discussion of some lessons that can be gained from Berle's work for people interested in democratic and progressive banking reform today. Specifically, we draw three lessons for a theory of democratized finance that are consistent with Berle's work. Firstly, Berle addressed the shortcomings of his competitors. In that spirit, we believe proponents of democratized finance should ring the alarm about private equity's encroachment on public infrastructure. Secondly, Berle stressed precedents for government action as justifications for further reform. Here we argue for a closer focus on the trillions in loans currently owned or guaranteed via federal credit programs. Thirdly, Berle regularly articulated core principles and essential elements. In that tradition, we offer a distillation of the overarching principles that might guide democratic financial reform today. Specifically, we posit three pillars, or primary orienting principles: fair allocation, local and global sustainability, and political accountability.

\section{Why Berle?}

There were many proposals for banking reform circulating in the 1930s, so why focus on Adolf Berle's? We believe that Berle's plan is particularly noteworthy because he was one of the nation's great thinkers of democratic accountability and finance. The Modern Corporation and Private Property, his classic book co-written with Gardiner Means, was a landmark of organizational scholarship that helped establish corporate governance as a field of study. ${ }^{2}$ Moreover, Berle paired scholarship with a remarkable career. As a Wall Street lawyer, a member of Roosevelt's brain trust (initially called the "brains trust"), and legal counsel to the 
Reconstruction Finance Corporation (RFC), Berle held an insider's perspective and exercised influence at the upper-echelons of U.S. politics. This section outlines Berle's personal history, intellectual contributions, and political work - all of which helps us make sense of the logic and stakes of his modern financial toolkit.

\section{From the Social Gospel to Corporate Finance}

Adolf Augustus Berle Jr. was born in Boston on January 29, 1895, second of four children. His mother, Augusta Write, was from a well-off New England family and did missionary work with the Sioux Indians after graduating from Oberlin. Berle Sr. was a Congregationalist minister ("one of the most controversial and forward-looking clergymen of his day," according to the New York Times) and a professor of applied Christianity at Tufts. ${ }^{3}$

A proponent of the Social Gospel, the Reverend Doctor Berle traveled the nation giving lectures on the importance of efficiency in public school education. The four Berle children were homeschooled year-round according to these theories of child development, which included a belief that children should learn language before mathematics. Berle Sr. was an autocratic taskmaster, and the children performed accordingly: the two boys started Harvard at the age of 14, the two girls started Radcliffe at $16 .{ }^{4}$ Adolf Jr. passed Harvard's entrance exam by 12 , although due to his young age he did not enroll until age 14. He went on to earn a B.A. at 18, an MA at 19, a law degree at 21, all from Harvard. Berle Sr. frequently invoked his children's accomplishments while on the lecture circuit. "Do not say prodigy to me." The senior Berle was quoted as saying, "Prodigies do not come four to a family."

Active in progressive circles, the Berle family socialized with luminaries like Jane Addams, Lillian Wald, and Louis Brandeis. This all had a lasting impact on Adolf Jr. "He 
entered adulthood," writes Journalist Nicholas Lemann, "fully persuaded that taming of the power of centralized business was the great historic task facing the country." ${ }^{\prime 6}$ In that spirit, Berle Jr., like his father, saw drastic economic reorganization as a means to social reform.

During his senior year in college, Berle provided research assistance to Edward Channing, who was writing his Pulitzer Prize winning History of the United States. Under Channing's supervision, Berle wrote his own master's essay on Alexander Hamilton's Assumption Act. ${ }^{7}$ Also known as the Funding Act of 1790, the act led to the issuance of the first U.S. Treasury securities and allowed the federal government to assume state debts. This work presaged Berle's future proposals to use centralized federal credit as remedy.

It was partly through his beliefs and partly through his father's guidance that Berle ended up pursuing law. ${ }^{8}$ The close relationship between social reform, law, and the economy was established early on in Berle's life. After graduating Harvard, he spent a year in Brandeis's law firm, and then left to join the army near the end of World War I. There, among other things, he served on committee charged with negotiating the Treaty of Versailles. After the war, he opened a law practice with his brother. The office was located on 70 Pine street in New York, a block off Wall Street, and three short blocks to the Stock Exchange. Berle's work on Wall Street that gave him deep insight into corporate finance and the relative position of shareholders in modern firms. In these years, Berle frequently wrote for magazines like the Nation and New Republic. ${ }^{9}$

In 1927 Adolf married Beatrice Bend Bishop, an heiress, intellectual, and reformer in her own right. First trained as a social worker, Beatrice sometimes taught psychology and sociology at Sarah Lawrence. She later attended medical school while their three children were still at home. ${ }^{10}$ The year they married, Berle received a grant from the Social Science Research Center to start work on a study of corporate finance. He subsequently joined the faculty at Columbia 
Law, which would thereafter serve as the institutional seat of his research. He also hired a graduate student in economics, Gardiner Means, to work on the project. " "To their collaboration, Means brought an original and capacious economic intelligence," writes Arthur Schlesinger. "Berle, a few months the senior of the pair, [brought] both the finicky precision of a legal technician and the broad perspectives of a social prophet." ${ }^{, 12}$

The Modern Corporation and Private Property

Berle's great intellectual triumph -The Modern Corporation and Private Property - was also the achievement that opened the door for his future as a statesman. Work on the book began in 1928. Berle and Means oversaw a team of graduate students who amassed statistical data on corporate power and consolidation. Published in 1932, Modern Corporation immediately made waves. An executive at General Motors read an early copy and successfully pressured the publisher's owner (the Corporation Trust Company Commerce Clearing House) to drop the book. MacMillan picked up the title, giving it an even larger distribution than it might have otherwise had.

Reviewers sang its praises. In The New Republic, socialist economist Stuart Chase called the book "epoch shattering." 13 Preeminent historian Charles Beard called it the most important work on American statecraft since the federalist papers. Berle's protégé John Kenneth Galbraith would later deem it one of the two most important books of the 1930s, alongside Keynes's General Theory of Employment, Interest and Money. ${ }^{14}$

To understand the book's immediate success, one must take into account the timeliness and social relevance of its subject matter. Americans had debated the pros and cons of rising corporate power for decades. The onset of the Great Depression added a fresh sense of urgency 
to those debates. Economic catastrophe had tarnished the right's preferred "hands-off" stance and created a window of opportunity for the left, but had its its own internal divisions to overcome. Historians sometimes group the cross-cutting and shifting tangled of New Deal alliances into two camps. On one side were the antitrusters and anti-monopolists who wanted to break up corporate power. On the other side were planners that sought to harness corporate power. ${ }^{15}$ Despite the fact that Berle had worked for Brandeis, the leading proponent of breaking up the power of corporations, Berle himself had moved toward the approach typified by Teddy Roosevelt, one that called for a stronger central government as a force that could counterbalance the accrual of corporate power. Berle believed that corporations were here to stay. The best path forward was to redirect the modern corporation toward a broader civic agenda.

Today Modern Corporation is most famous for its discussion of the separation of corporate ownership from control. The book painstakingly details decades of court decisions that conferred power over corporate resources to the managers, and the subsequent dilution of shareholders' discretionary capacity over the use of corporate property. For Berle and Means, that this separation of ownership and control "split the atom" of property rights and destroyed "the very foundation on which the economic order of the past three centuries has rested."16 These ideas, alongside Coase's work on transaction costs (published five years later), became the foundation of corporate governance theory. And because the Modern Corporation continued to be read largely from within the field of corporate governance, it was remembered primarily for the things later scholars of corporate governance cared about, namely, the idea that shareholders had lost control of the firm. Berle and Means had presaged agency theory, which would work to align the interests of managers with those of the shareholders. Consequently, The Modern Corporation is remembered by many as a treatise on shareholder rights. 
There is no small irony that the book is known today simply as a defense of shareholders. ${ }^{17}$ As scholars like Delia Tsuk and Mark Mizruchi have noted, a narrow focus on shareholders betrays the breadth of Berle and Means's critique. ${ }^{18}$ Berle and Means pressed readers to rethink the foundations of the modern corporation. The main lesson was that corporations were quasi-governmental entities with so much power, over so many people, that they had become law-creating entities in their own right. Corporations, in other words, were essentially little governments, and undemocratic ones to boot. There is no great difference between having all industry run by a committee of Commissars and by a small group of Directors." ${ }^{19}$ Recast as governments, it was possible to see corporations as organizations beholden not simply to the needs only of shareholders but also workers and consumers. ${ }^{20}$

Berle and Means's endgame was not shareholder's rights. It was civic accountability for the modern corporation.

\section{Berle and FDR}

While Berle and Means's larger critique is often overlooked today, that was not the case when it was published. Columbia political scientist Raymond Moley passed the book along to then-governor and presidential candidate, Franklin Delano Roosevelt (FDR), and Moley invited Berle to prepare materials on "credit and corporations." ${ }^{\text {21 }}$ Berle had reservations. He had been a progressive Republican and an active member of the party until 1928. Moley assured Berle that it was his technical expertise, not political support, that the brains trust needed. ${ }^{22}$ Assuaged, Berle signed up. He would become a central player. Notably, Adolf and Beatrice together wrote the Commonwealth Club speech, famous for its early articulation of New Deal principles. ${ }^{23}$ 
With FDR's electoral victory, The Modern Corporation became the "economic bible" of the new administration. ${ }^{24}$ Berle rejected FDR's offer to Chair the Federal Trade Commission, believing that he could be more influential as a an informal advisor. This also freed Berle up to serve as advisor to New York's legendary mayor Fiorella LaGuardia. ${ }^{25}$ Berle did, however, accept a position as legal counsel to the RFC. That appointment ended in 1933, but Berle remained friendly with its powerful president, Jesse Jones. ${ }^{26}$ Berle participated in politics throughout his life as an advisor, appointee, fundraiser, and organizer. After 1937, when an inheritance from Beatrice's family gave their family new financial security, Berle retired from law. In 1938, he accepted a position as Assistant Secretary of State for Latin Affairs. Founder and leader of New York Liberal Party, Berle backed strong government but campaigned vigorously against anyone known for communist sympathies. He died of a stroke in 1971.

"A short, intense, small boned man with the energy of a dynamo," wrote the New York Times in his obituary, "Mr. Berle had a brilliant mind, and, according to some New Dealers whom he rubbed the wrong way, he knew it." ${ }^{" 27}$ Caustic and combative, he was "one of Washington's most disliked figures," and peers disparagingly referred to him as a Little Atlas or The Brain. ${ }^{28}$ "Berle had had a whirlwind career as an infant prodigy in Harvard College and Law School." Moley's memoir quips, "Someone has been so unkind as to suggest that he continued to be an infant long after he had ceased to be a prodigy." ${ }^{29}$ Moley then softens the blow by enumerating Berle's formidable talents: "But I always found that the slightly youthful cockiness and brashness to which this strained epigram referred was more than compensated for by the toughness of his mind, his quickness, his energy, and his ability to organize material well.”

How does this background inform a reading of Berle's banking proposals? At base, Berle's personal history shows that his proposals are the work of a prominent intellectual with a 
deep well of knowledge of the nation's political terrain. Beyond that, this background situates his banking plans as part of a larger project of corporate accountability. Berle worked on Wall Street. He was a proud liberal and staunch anti-communist. He was no socialist. But raised in the Social Gospel, influenced by luminaries like Brandeis and Wald, Berle saw in the evolution of capitalism an array of possibilities for corporations to serve the public good - provided that they were guided by higher principles and subject to government oversight. Berle believed that the right kind of management could yield "a collectivism without communism" in which a capitalist economy ultimately served not individual profit but "the national life as a whole." 30

\section{The Larger Context for the Proposals: New Deal Banking Reforms}

Most people are well aware of the economic reforms put into law during the New Deal: the implementation of deposit insurance, the separation of commercial and investment banking through Glass-Steagall, the formation of the SEC, the restructuring of the Federal Reserve. Less well known are the plethora of additional proposals that circulated at the time. If we look specifically at the latter-half of the 1930s, when Berle set forth his ideas for a modern financial toolkit, it becomes clear that his efforts were emblematic of a larger set of ongoing debates. "The country needs and, unless I mistake its temper, the country demands bold, persistent experimentation." Roosevelt said in his 1932 speech at Oglethorpe University. "It is common sense to take a method and try it: If it fails, admit it frankly and try another. But above all, try something." 31 Encouraged by FDR, emboldened by crisis, Berle's work on financial reform unfolded in an environment that proved fertile ground for the cross-pollination of policy ideas. Berle's Earlier Work on Credit Reform 
Berle's early work on banking reform started before FDR was in the Oval Office. In May of 1932, six months before Roosevelt's election, Berle and Louis Faulkner, of the Bank of New York and Trust Company, presented Roosevelt with a comprehensive overview of the economic crisis and recommended policies that became central New Deal programs. In addition to reiterating The Modern Corporation's warnings, the Berle-Faulkner proposal (and other early work for Roosevelt) emphasized two things. First, that the economic system should be managed to provide people with stable employment and a livable wage. Second, that the credit system and social insurance could be tools for ensuring economic stability. ${ }^{32}$

Berle and Faulkner based their recommendations on the principle that "as a matter of sound economics and decent humanity, an economic policy of the government ought to be adopted towards the restoration of individual safety." ${ }^{\prime 3}$ In Berle's view, Hoover, who preached individualism as a rationale for limiting government assistance to struggling Americans, misunderstood the term. To Berle, a "far truer individualism" viewed economic security as a necessary condition for individuals to thrive. ${ }^{34}$ For this reason, Berle rejected alternative New Deal proposals that would save corporations but leave individuals to fend for themselves. ${ }^{35}$ Banking reform was key to fixing the economy. With deposits withdrawn at a rate of $\$ 100$ million dollars each week over the prior year, Berle and Faulkner honed in on the need to ensure depositor confidence in order to prevent bank failures. The idea of protecting depositors had long circled around congress. It was finally achieved with the creation of the Federal Deposit Insurance Corporation (FDIC). ${ }^{36}$ Berle and Faulkner also proposed farm credit support systems that were enacted with the creation of the Home Owners' Loan Corporation (HOLC) and the Farm Credit Association. The proposal further backed the expansion of the RFC, old age pensions (Social Security) and unemployment insurance. 
The 1932 proposals presaged Berle's later proposals for a modern financial toolkit. Berle and Faulkner recommended that low interest, guaranteed loans be provided to companies that committed to maintaining employment levels, particularly for projects benefiting their communities. For longer run stability, Berle and Faulkner called for a federal board which could monitor security sales, a function that would be fulfilled by the Securities and Exchange Commission (SEC), and "could exercise a real control over undue expansion of groups of credit instruments, where issue of these reached a point threatening the safety of the financial structure." 37 This last goal was not addressed until the 2008 financial crisis prompted the creation of the Financial Stability Oversight Council as a component of the Dodd-Frank reforms. ${ }^{38}$

\section{Other New Deal Proposals}

Berle's more developed prescriptions for a modern financial toolkit drew from and consolidated many ideas that were debated at the time. His proposals stood out not for their novelty, but for their comprehensiveness, and for their explicit discussion of motivating principles. Table 1 contains a summary of several plans in circulation during the Late-New Deal, including that of Berle's. None of these plans were instituted, with the exception of a limited expansion of RFC small business lending in the late 1930s. These later New Deal banking reform proposals can generally be categorized into four groups, based on their focus and approach: (i) the small business reforms, (ii) targeted solutions, (iii) radical overhauls, and (iv) defensive countermeasures.

[Table 1 around here] 


\section{Targeted Solutions}

Some reform proposals focused on changing the financial system in ways that were dramatic but sharply defined in scope. Here we focus on two of them: calls for small business credit provision, and calls for accounting changes.

James Mead, the Democrat junior Senator from New York, led the effort to expand small business credit. In Spring of 1939, Mead proposed a bill that mandated the RFC to offer loans of up to $\$ 100,000$ for plants, equipment or operations. A second bill proposed that the RFC provide a $90 \%$ guarantee for 10 -year loans of up to $\$ 1,000,000 .{ }^{39}$ RFC lent only to businesses turned down by local bankers. These bills would be a significant expansion. Mead wanted a system for small businesses that filled the "no man's land" of private credit for small businesses, much as the Home Owners Loan and Farm Credit Association had done elsewhere.

The hearings on the Mead bills began in late May 1939. They provided a forum for stakeholders - including small business owners, representatives of the American Banking Association, Jesse Jones, and Marriner Eccles of the Federal Reserve - to weigh in on small business loan program proposals. Mead's bills received support from establishment figures, such as Fed Governor Ernest Draper, SEC Chairman Jerome Frank, and Commerce Secretary Harry Hopkins. ${ }^{40}$ However, they were opposed by Bankers, some Democratic Senators and perhaps most importantly, by RFC-head Jesse Jones. ${ }^{41}$ At his appearance before the committee in June 1939, Jones strongly resisted any financing mechanism beyond the existing capabilities of the Federal Reserve and the RFC. Jones noted that the Federal Reserve had authority to make business loans, but the volume was low, indicating that the market was working. With regard to the RFC's loan program, Jones told the committee, “Any deserving borrower who can furnish security that will reasonably assure repayment of his loan can have a loan if he will apply to the 
RFC for it, and on very generous terms, provided the loan will serve a useful purpose and is consistent with the law." ${ }^{\not 2}$ The decision as to who was a deserving borrower, what counted for security and what constituted a "useful purpose" would of course be left with the RFC. Jones, who in fact had no desire to extend the RFC's reach into small business loans, did reluctantly oversee an expansion of small-business loans in the post-1938 period, perhaps as a way to prove his assertion of the liberalness of the RFC's loan standards. ${ }^{43}$

Another type of forward-looking but targeted reform concerned the accounting standards used in the federal budget. We can see this in the remarks of Alvin Hansen, a Keynesian economist from Harvard. Hansen suggested that the government consider separating the budget into an operating budget and a capital budget. Accounting for capital expenditures separately, as a business would, might allow the government to allocate costs and depreciation over a period of years. This would prevent the incursion of an immediate, lump sum charge, and make it easier for the government to spend money or issue loans outside of the already off-budget RFC. Hansen thought that the severity the economic depression heightened the need for separate budgets. Opponents of capital budget reform saw the proposal as a threat to small government. This critique is exemplified by Lehman Brothers economist Alexander Sachs, who was keenly read and followed by Roosevelt. ${ }^{44}$ While acknowledging the need for federal spending on things like regional economic development projects, Sachs argued that big government was the main threat to democracy. Capital budgeting would make the government seem smaller than it actually was. Better for the state to look larger to the public, lest people decide it had plenty of room to grow.

The Roosevelt administration tried to get around the lack of a capital budget by moving more government programs -- for railroads, rural electrification, toll roads, and other capital projects -- off budget. With the support of the administration, Kentucky Senator Alben Barkley 
and Alabama Representative Henry Steagall sponsored a bill that would allow the off-budget RFC to issue bonds on behalf of agencies like the Department of Agriculture and Public Roads Administration. ${ }^{45}$ Though Jones, Morgenthau and Eccles all spoke in support of the bill, it did not receive universal support from Democrats, and Republicans denounced the bill as "Socialism by stealth," that enabled pork barrel politics and constituted a form of "subterfuge to raise the legal debt limit." The House declined to bring the legislation to a full vote. ${ }^{46}$

\section{Radical Overhauls}

Unlike more focused changes to extend credit to small businesses or to reform government accounting rules, more radical reformers envisioned a system-wide transformation. We see this with California Congressman Jerry Voorhis' bill proposing a Public Works Finance Corporation. Voorhis, like Berle, was an adherent of the Social Gospel. Voorhis felt that the government should not have to take on any debt at all to create money. "Why in Heaven's name cannot the United States Treasury," Voorhis asked, "with greater reserves than any bank possesses, buy the bonds of the Housing Authority, the P. W. A., or of a State or county by the same process of credit creation that the banks now employ?"47 After reintroducing his bill in 1939, Voorhis approvingly quoted Berle's plans (discussed below) as an argument for funding his proposed Public Works Finance Corporation. Voorhis had a larger agenda of nationalizing the Federal Reserve, allowing the Treasury to fund programs without issuing debt and eliminating fractional reserve banking. Voorhis' memoir relates that Roosevelt agreed to the Fed nationalization plan for a period of roughly two hours until Fed chairman Eccles intervened. Voorhis is best known for being the first victim of Richard Nixon's no-holds-barred red-baiting 
approach to politics, losing his seat in Nixon's first campaign after allegations that Voorhis was a supporter of communism. ${ }^{48}$

Florida Senator Claude Peppers’ plan for Regional Industrial Banks was similarly bold in its approach: it would create a system of regional industrial banks, one of which would be owned by the Treasury. ${ }^{49}$ Each bank would begin working with a capital stock of $\$ 100,000,000$. The stock of each could later be increased up to $\$ 1,000,000,000$ with a possibility of their acquisition by the public. Treasury ownership of the banks meant that lending policy would be constrained by neither the independent Federal Reserve nor the conservative standards of Jones's RFC. In hearings for the Mead Bill, Pepper said he introduced the bill because "investment bankers are not interested in the little fellow ever, and in the second place, they are interested in the big fellow only when they can quickly dispose of his security issue at a profit to themselves." ${ }^{50}$ The regional industrial banks would be Treasury owned banks that could invest in equities as well as long term loans, both of which were difficult to come by. Neither the Peppers nor the Voorhis plan went anywhere in Congress. ${ }^{51}$

\section{Defensive Countermeasures}

Proposals for incremental change of existing institutions were supported by Jones and Federal Reserve Governor Marriner Eccles. In 1939, as the Mead bill was created, and around the time that Berle would propose the creation of a new system of credit banks, Eccles proposed the formation of a new industrial loan corporation from within the Federal Reserve System. Eccles further suggested that his proposal might be incorporated into the Mead bill, even though it was fundamentally incompatible with Mead's RFC-based approach. Making his case, Eccles offered a critique of Mead's plan: he argued that it would not entice banks to lend because of the 
potential $10 \%$ loss on insured loans and the limits imposed on loan interest rates. Instead, Eccles offered a counter-proposal that would keep authority centered in the Federal Reserve. In this approach, the Fed's existing business-lending powers would be replaced with a new corporation that operated out of the Fed's existing regional banks and overseen by the Fed Board of Governors. Eccles claimed that his plan would offer commercial and industrial enterprises funds on a "sound but liberal basis, for long periods of time if that were necessary and desirable." 52 Make no mistake: the Eccles program was a defensive maneuver. Though Eccles clearly preferred his plan to the Mead plans, he also cautioned against its implementation. "I do not believe that this or any other similar loan plan which has been or might be offered," Eccles explained, "however desirable, as an improvement in the existing mechanism for facilitating the flow of funds for small business, will or can in itself be material in bringing about a substantial business improvement. ${ }^{{ }^{53}}$ It is no coincidence that both Eccles and Jones resisted substantial legislation to modify the credit system. The Federal Reserve Board had already suggested a longterm Congressional study of the banking system, but Eccles was afraid of a rushed, piecemeal approach to reform. At an interdepartmental meeting a few short months before the Mead bill was introduced, Eccles told Jones and other senior banking officials, "As a practical matter, I know damn well that no such committee should develop legislation. ${ }^{" 54}$ For his part, Jones concluded that no bank reform legislation was needed, and no Congressional study of the banking system was even necessary. ${ }^{55}$

In this context of the above policy proposals, Berle's own approach to reform stood out for its articulation of a coherent rationale and motivating philosophy. Berle's integration of principles from law, economics and social change would make his outlook more inclusive than more defensive or narrowly targeted reforms. His careful promotion of government involvement 
in cases of national interest, without socialist affiliations, would distinguish Berle's plan from the more radical proposals.

\section{The Immediate Context for the Berle Proposals}

The Temporary National Economic Committee (TNEC) provided the immediate context for Berle's own proposals for banking reform in 1938 and 1939. The TNEC itself was a response to the recession of 1937-1938. Between May 1937 and June 1938 real GDP dropped by 10\%, unemployment hit $20 \%$, industrial production fell by $32 \% .{ }^{56}$ Antitrusters like Leon Henderson (an economics professor from Swarthmore) had angled for years for a stronger response to the concentration of corporate power. Now those antitrusters pressed their case. Historian Ellis Hawley summarizes their argument: "American capitalism had been sustained from the beginning by federal intervention, by such expedients as the public land grants, wartime spending, protective tariffs, and deficit financing. If this were true, it seemed obvious that the government would have to intervene again. ${ }^{, 57}$ With arguments for a federal answer to the antitrust question, Hawley concluded that the TNEC was an "escape mechanism" for FDR, because an investigation was the least controversial way for him to address the divisive matter. ${ }^{58}$ While it was convened by Congress to investigate monopolies, in the New Deal historiography the TNEC is best known for the role it ended up playing in helping to popularize Keynesianism.

When considering Berle's proposals for the TNEC, it is necessary to keep in mind the particular historical moment. This was late in the New Deal. Budget hawks like Treasury Secretary Henry Morgenthau, Jr. nearly talked FDR into killing the RFC before the recession, and it seemed like they might do so again - they wanted to use its funds to balance the budget, a goal FDR publicly espoused in $1938 .{ }^{59}$ We know in retrospect that the second world war would 
soon cause a surge in RFC activities, but Berle had good reason to believe that even a surviving RFC would not be as progressive as he would like. Consider the matter of lending to small business, an unmet frequently discussed in these years. The RFC began lending money to businesses in 1934, and within four years lent $\$ 500$ million through 9,000 loans, often via partnerships (sometimes private banks that provided part of the capital; sometimes the RFC offered to purchase loans at a later date, effectively using put options to spur private lending). ${ }^{60}$ These RFC business loans overwhelmingly focused on manufacturing and medium-sized firms, however, and Jesse Jones, the powerful head of the RFC, resisted Berle's calls for more lending to small borrowers. ${ }^{61}$ The RFC also made no loans to hospitals because Jones felt hospitals should be supported by their local communities. ${ }^{62}$ While Berle and Jones were friendly, the memoranda suggest Berle's willingness to work around Jones's RFC. This was part of the policy backdrop for Berle's proposals.

We should also keep the timing in mind when considering Berle's political clout. At 43, Berle was embarking on his career as a diplomat as Assistant Secretary of State. He had passed the high point of his policy influence. The period historians refer as the "Second New Deal" (a push starting in 1935 best known for the Works Progress Administration, Social Security, the National Labor Relations Act) brought into prominence a new wave of Brain Trusters, a group that included Berle's longtime nemesis Felix Frankfurter, who hewed to a Brandeisian strategy of breaking up corporate power. Berle now moved within a more crowded field of experts, and he did so at a time when the New Deal was losing steam.

The 12-member TNEC, made up of congressmen and agency heads, was something of a microcosm of the larger divisions of the entire New Deal. The planners set against the antimonopolists, who set against the defenders of market competition in turn. Berle sat in the 
planning camp, which had already lost some big battles by $1938 .{ }^{63}$ For Berle and the other planners, the TNEC provided a fresh opportunity to realize their vision, provided they could neutralize the anti-monopolists.

As soon as the TNEC convened Berle drafted a memorandum, "Investigation of Business Organization and Practices." The memo was promptly leaked, and its publisher later reported that government agencies were "flooded with requests" for copies. In his personal papers, Berle filed "The Investigation of Business Organization and Practice" alongside his larger plan for banking reform, titled “A Banking System for Capital and Capital Credit.” Berle's own files therefore indicate that we should treat the two memos as a set. ${ }^{64}$

\section{Banking and the Big Picture}

Berle's memo on "The Investigation of Business Organization and Practice” reads as an economic primer for TNEC members. Its rhetoric reflects Berle's efforts to position himself relative to other New Dealers. On the one hand, he stresses his progressive bona fides by privileging the wellbeing of workers and consumers relative to corporate profits. On the other hand, Berle sets himself apart from those farther left by stressing the protection of individual liberties, and openly rejecting socialism as a desirable path forward.

As a kind of primer, the memo covers a good deal of ground. It opens with a discussion of the role of the government in the economy, and then details how differently sized companies have different levels of productivity, different sorts of advantages, different patterns of innovation. Berle next addresses the matter of concentrated corporate power, and urges the committee members not to focus on property ownership but control (or "power") that is 
exercised through board interlocks, lines of credit, patent licenses and restrictions, and supply chains. Berle recommends that when evaluating industries, the TNEC members consider not just profits but the interests of consumers, labor, and managers. Finally, Berle entreats the committee to make explicit the principles behind its recommendations, warning that the failure to do so leaves a regulation vulnerable to misinterpretation or regulatory capture. ${ }^{65} \mathrm{He}$ valued both transparency and democratic oversight.

The memo repeatedly pushes back against the antitrusters. Berle argues against a uniform approach to the economy, stressing that "[t]here is no one-size fits all solution" to the organization of markets. ${ }^{66}$ Any solution should fit the structure of a specific industry: unfettered competition, cartelization, quasi-governmental enterprise or public ownership should all be viable options, depending on the context. Berle warns that small businesses are not necessarily competitive or humane, but are often just more localized monopolies ${ }^{67}$ Moreover, small businesses could not efficiently produce many of the products that consumers desired. While not necessarily or uniformly beneficial ("it is not clear that the standard of living would decrease if they [consumers] stopped wanting cigarettes or canned soups or cosmetics"), Berle felt that these industrial goods should nevertheless be provided: "people are entitled to want what they actually do want"; telling people otherwise "becomes tyranny." ${ }^{\prime 68}$ Cartelization may be appropriate where "planning of output is inherently necessary," which includes motors, oil and possibly copper and textiles. ${ }^{69}$ It is dangerous, Berle states, to break up large business when resulting unchecked competition would be wholly destabilizing. "You cannot gamble with the economic safety of a large district simply in the hope that the expansion of inventory will lower price."70

While making these arguments, Berle makes a set of rhetorical moves of particular note: 
- Guiding principles: For the TNEC, Berle proposes a three-part test to evaluate an industry: (a) Is there an adequate supply of goods based on the normal standards of the market and apparent need? (b) Can a maximum number of people make a living and support their families out of poverty? (c) Is this all accomplished "with due regard for the liberty and self-development of the individual?"

- Need for government action. Berle builds a case for a more active government in the economy. Large corporations might be necessary for certain markets, but it does not follow that we can trust corporations to be fair or efficient. The size of the modern corporation means that it can "outrun the moral and mental stature" of managers, and what seems like efficiency may actually be the result of large corporations' capacity to impose externalities. Corporate efficiency, Berle notes, "may merely mean a plant which has succeeded in unloading the maximum possible amount of obligations on the community." ${ }^{, 71}$ A truly efficient corporation is one that provides an adequate supply of goods and adequate employment without imposing externalities.

- Precedents for government action. The memo shows that it is not private efforts alone, but a unity of public and private initiative, that allows markets to thrive. Berle lists various ways the government supports business. Patents and trademarks subsidize industry by effectively granting monopolies (as with utilities). Tariffs and price controls protect businesses. Large purchases (like wartime purchases from Bethlehem Steel) boost sales. The memo lists other indirect forms of support and subsidy: public infrastructure, like roads, without which many private businesses could not exist; health efforts that 
drive down insurance rates; poor relief, which is a subsidy insofar as it reduces labor costs. If the full scope of government support for business was recognized, "[a] slightly different view of "private initiative" would probably emerge from such a picture."72

- Metrics of success. How should the government go about building a better economy? On the first page of the first memorandum, Berle advocates for the government to use a "triple income statement" to evaluate the industrial system's impact not just on investors but also for labor and consumers: Does the industry provide steady work for decent pay? Is the output useful and distributed at a reasonable price? And does the industry provide a decent work-life for laborers, so as to mitigate disruption due to innovation? How this would actually be calculated goes unsaid. What matters for Berle is the idea that such a technique could guide the TNEC's evaluation of different industries.

Berle closes the memo with a high-level view of an ambitious program to use the control provided by corporate licensing to provide more and better goods, jobs, and access to capital. This process likely entails different tactics for different industries. It is in this section that Berle broaches the subject of a system of capital credit banks backed by a capital reserve bank. He further elaborated these ideas in the middle of 1939, with a memorandum for the TNEC entitled, “A Banking System for Capital and Credit." It is to this second memorandum that we now turn.

\section{A Banking System for Capital and Capital Credit}

“A Banking System for Capital and Credit," provides a deeper dive into finance for members of the TNEC tasked with an investigation of investment banking. Berle considered this 
20-page memorandum a "general guy-wire." ${ }^{" 73}$ Like the previous paper, it offers guiding principles rather than detailed instructions for policy design.

Berle begins with a diagnosis of the problem at hand. The United States has the skill, drive and natural resources required for a thriving economy, Berle writes, so a failure to deliver on full employment must be due to some sort of "malorganization." Berle blames the financial system. It does not work and must "be supplemented by vast amounts of Federal credit which make up in some measure, but inadequately, for difficulties in the existing system of private finance." While the rise of central banking has modernized the field of short-term credit, long term capital markets have not followed suit. The bond business, for instance, is much the same as it was at the time of Napoleonic Wars and the British East India Company. "We have no really modern system of long-term finance," he laments. ${ }^{74}$ But why shouldn't the government now do for long-term economic development what the Federal Reserve did for short-term credit?Part of problem is that Americans have neglected new economic theories. In addition to discussing Keynes, Berle spends time discussing the work of Chicago institutional economist (and first president of Brookings) Harold Moulton. Moulton's “discovery," Berle summarized, was "that a large part of what had been assumed to be "savings" - that is, the money destined for long-term investment - was not different from any other kind of created bank credit.” Long-term investment could be stimulated by "properly controlled banking operations." Just as there is no need to allow banks to collapse in times of crisis, there is no need to stop investing in capital assets during downturns, provided that there is underused capacity. ${ }^{75}$

Berle specifically identifies four main underlying causes for financial malorganization. First is "the restricted base of national enterprise." The rise of totalitarianism has led to nationalized markets, and this in turn hurt American exports. The second underlying cause is the 
rise of "needed social services" caused by rapid economic growth. Rapid economic expansion has elevated social needs beyond the market's ability to meet them. This includes a need for infrastructure, like bridges. It also includes a sense of relative poverty that has increased people's wants ("Whether the needs are logical or psychological, they are real enough."”6); and social ills that arise from rapid changes like urbanization (which increase the need for hospitals, for example). Private finance is unable and unwilling to meet many of those needs.

"The Fears of Capital and Capital Groups" is the third underlying cause of financial disorganization. Here Berle observes that when investors become afraid of economic loss during downturns, they hoard capital. In this context, investors complain that additional government intervention or any additional taxation will further scare them away from the market. Berle acknowledges this, but with limited patience for threats of capital flight or hoarding. "There is something in all these contentions, but probably all have been exaggerated entirely out of measure ... Prophesies of complete stoppage or complete disaster have been made whenever any reform has been undertaken; and they have usually proved unfounded once there is acceptance of reform." ${ }^{" 77}$ Investors might threaten to exit the market when faced with an expansion of state power, but that does not mean they actually will.

The fourth and final underlying cause of financial disorganization is a failure of marketmaking for public goods, which Berle calls a "Need for a Causative Mechanism." For Berle, there are a set of needs that are social, rather than commercial, that banks neglect due to a combination of profit-motive and regulatory constraints (read: Glass-Steagall). In these cases, government must take on a more active role and provide capital to spur businessmen into action. Long term capital has stagnated, and is in desperate need of "new processes, new products, new developments, and new methods." ${ }^{.78}$ A new system of capital credit banking can help with this. 
The Solution: A Modern Financial Toolkit

The second half of the memo discusses solutions. Here the argument culminates with three recommendations for future TNEC action:

1. A bill for a Public Works Finance Corporation. This would use Federal Reserve privileges to ease the issuance of credit for both federal and local infrastructure projects. It would be off-budget and provide low interest rates for non-profits.

2. A bill for Small Business Loan insurance. This would allow small businesses to more effectively compete with large businesses.

3. A committee to investigate policies for capital credit banks for underserved public and private enterprise.

Together, these three steps make up a "modern financial tool-kit" that would allow the capital system to fully employ the productive capacity of the United States. These are not "a panacea," Berle writes, but "tools so that initiative and ideas can go to work." ${ }^{, 79}$ Berle offers few details for each individual proposal, perhaps because he thinks the centerpiece - the system for credit banks - should be designed by a TNEC subcommittee. Later congressional testimony indicates that others believed that if Berle's new banking system was indeed put into place, the need for the other proposals would be obviated. ${ }^{80}$

Berle posits many possible ways for a system of capital credit banks to work: banks could take deposits or issue bonds; the entities could be part of an entirely new or existing system; a plan could be organized on a national or regional basis; or be created by functionally dividing up different banks (e.g., into a manufacturing specialist, a transport specialist, etc.). No matter the approach, a breadth of customers could be served: individuals, companies, municipalities, and 
semi-public authorities. No matter the approach, certain "essential" goals must be met. A new system should provide (1) cash for investment in (2) commercial and noncommercial wealth (like public infrastructure, low cost housing, and hospitals) that has (3) flexible interest rates over time, and (4) selective interest rates (that is, rates that vary based on the social value of the investment), but (5) not offer too much credit (investments should be limited to really productive things) and (6) not be too inflationary; in fact, at multiple points he returns to the idea that the banks must somehow be connected to the Federal Reserve. The system should also (7) serve public needs and never be "cut off merely through private motives." 81

\section{Lessons from the Second Memo}

Berle's second memo makes a set points that we believe are worth stressing:

- A defense of non-profit banking. Berle states that a bank's ability to make a profit is created by a government-granted ability to create currency by lending based on fractional reserves. Berle likens the ability to make profits from a government-granted privilege to "tax-farmers" rights to keep a cut of what they are authorized to collect. Because they are dependent on a government privilege, banks need not maximize profits. Their main task is "to keep an even flow of capital constriction and to see that the country is well served." 82 While a new system could possibly be made up of private entities with well-paid managers, there need not be a return to shareholders.

- "Selective" interest rates. Berle repeatedly touches on the idea of "selective" interest rates. Because the new system should prompt the creation of public wealth, higher interest rates should only be given to for-profit enterprises. When the "community as a 
whole is paying" for public goods and non-profits, the interest rate should be a reserve to cover losses. The only reason for a high interest rate in that case would be to discourage overbuilding. As long as the amortization rate is set so that the loan is paid off within the life of the asset (making the loan "self-liquidating") the system will be sound.

- Political ramifications. Frequently mentioning the rise of totalitarianism, Berle paints his plan as a preventative measure. "Either we are on the eve of a change in our financial system; or we are on the eve of a change in our social system," he warns. ${ }^{83}$ That said, Berle offers no guarantees. It may be that the U.S. will become socialist; if so, the banking reforms he proposes will still be able to work. And he acknowledges that none of this may matter if there is another world war.

- Avoiding nationalization. In his efforts to distance himself from socialism, Berle addresses the question of nationalization of businesses. "I am frankly in favor of public ownership of certain forms of wealth," he asserts. ${ }^{84}$ But here he is circumspect. The government should only control industries that produce relatively uniform public goods. He notes that state efforts to fund production, depending on how it is organized, could lead to a kind of "drift" where over time the government effectively controls most of the productive capacity of the nation, because it has funded that capacity. ${ }^{85}$ His solution is therefore to have a system of capital credit banks that are non-profit and non-political, managed by professionals tasked with promoting the public good. ${ }^{86}$ 
- Democratic accountability. For the most part, Berle rejects the idea that his proposal is particularly divisive: business people simply want long-term credit, and will not care overly much about how that is arranged. That said, Berle sees his proposal as radical in its willingness to transform power over economic development from private hands to public oversight. He writes,

"Control over economic expansion today lies chiefly in certain groups mainly allied with the investment banking operation. Development of capital credit banking undoubtedly does shift that control. New centers are set up; centers which should be more responsible to the public, and carried on by groups which, by their nature, assume greater responsibility for maintaining a continuous economic flow." ${ }^{87}$

Here Berle comes to the crux of the matter: In the age of the large modern corporation, some relatively small and powerful group is going to control the nation's flow of long-term credit. Who will that group be, and what principles will they follow?

- Professional and institutional concerns. Berle regularly anticipates potential complications. To manage the threat of corruption, have an independent board of governors run the new system. To manage the threat of inflation, give the Federal Reserve oversight. Berle observes that bankers are trained to focus not on the nation's capital needs but on high returns; his answer is to pull employees from non-profits, savings, and mutual companies. And to prevent patronage politics, Berle suggests managers of the new banking system be barred "from political connection or office." 88 
In all, Berle's memoranda for the TNEC is the work of a liberal policy-maker taking care to distance himself from socialism while making a full-throated call for a mixed economy. Berle took the measure of a market must be holistically, with the wellbeing of workers and consumers placed alongside the accrual of profits. Finance was a crucial component of this vision. Later, testifying to Congress on these matters, Berle stated his point even more succinctly, echoing a common theme of the time: "I think the economic system is our servant and not our master, or, rather, ought to be." 89 Non-profit long-term banking must serve the public interest.

What happened to all these ideas? Our research uncovered vague references to Berle's proposals being "out of touch with the temper of the times." 90 In retrospect, we know that the New Deal's most energetic days were already over. FDR had more trouble getting many proposals through by this time. Republicans had forged an alliance with Southern Democrats to push back against expanded labor rights, starting a process of diluting its great accomplishments that would go on for years. ${ }^{91}$ The general history of the TNEC and New Deal indicates that some combination of war and shifting interests washed out the debate about banking.

\section{Three Lessons for Financial Reform Today}

While Berle's memoranda offer few details about actual policy design, they can nevertheless be mined for inspiration and insight. In the space we have remaining, we would like to highlight three themes, all in the spirit of Berle's vision, that we believe are especially promising.

Sound the Alarm on Private Equity 
Berle was never afraid to attack his competition. His call to action was not just grounded in what is currently going wrong, but what could be even worse. In the context of the TNEC, this meant calling out the dangers of inaction (a totalitarian turn) and the dangers of wrong action (antitrusters "gamble" with industries).

This strategy, we believe, is especially important when it comes to the encroachment of private equity on public infrastructure. America's infrastructure desperately needs capital, and political gridlock has thwarted traditional on-budget solutions. In the absence of a sudden and dramatic shift in political climate, something must give. If proponents of democratic finance do not provide Congress with a viable democratic solution to infrastructure finance, private-equity firms will gladly help implement an anti-democratic alternative, one that puts for-profit firms in charge of the nation's most essential shared resources.

The privatization of the public infrastructure has already started and can get much worse. Partnerships with private equity grant crucial decision-making capacities to a group of private firms that pride themselves on predatory resource-extraction..$^{92}$ Consider what we know about the Trump administration's infrastructure plan, which involves using incentives and partnerships to turn $\$ 200$ billion in federal funds into $\$ 1.5$ trillion in investment. ${ }^{93}$ This plan would likely give these companies the right to tax families (via tolls and fees) at the same time those companies' loans benefit from government guarantees. In other words, the citizenry would retain all the financial risks, while a group of private companies would capture any and all profits.

Private equity knows that elected officials do not want to raise taxes or be held accountable for debacles like Boston's Big Dig. ${ }^{94}$ Privatization offers an alternative, one that can be readily sold to a public primed to believe that market efficiency will always save costs. And 
they dismiss terrible warning signs, like the neoliberal austerity measures that ended up poisoning the people of Flint, as entirely irrelevant.

All of this means that if we do not want public infrastructure turned into for-profit enterprises, where elites keep all the profits while the public retains socialized risks, we must develop and defend a viable democratic alternative, and soon.

\section{Consider the Federal Credit Programs}

On what grounds does the government have the right to participate in credit allocation? Berle answers this by drawing on precedent. He reminds readers that the federal government already supports industry and banking, a reminder that is both a pragmatic (businesses regularly need help) and moral (societies get to make claims on profits that which it supports). Bob Hockett and Fred Block, in calling for a more democratic financial system, make the same move; both point out that the government has already entered the allocation business, through the RFC, farm and home loan systems. ${ }^{95}$ Such historical precedents matter, but we should not focus on them at the expense of a full account of what is happening today. We do not need to reach into our past for a justification for these plans, because the federal government today is extensively involved in the business of credit allocation.

Federal credit support did not end with the RFC, so much as it was recognized into a more decentralized system. In 1963, the House surveyed federal credit agencies and found that the government contained 74 separate credit aid programs, 51 of which issued loans directly, which together had amassed $\$ 30$ billion in assets, and insured or guaranteed another $\$ 70$ billion. While this system was highly concentrated at its core - three quarters of guarantees originated in the FHA and VA - it was also sprawling. The resulting report noted that "the credit programs 
extended to every segment of the American economy - financial institutions, agriculture, business, private housing, State and local government, international trade, and individual households." Through the credit programs, the federal government bolstered nearly every sector of the economy, and provided extensive backing to core industries: first agriculture, then housing, then education. These programs have been pivotal institution-builders. The Farm Loan Act promoted the use of the long-term amortizing mortgage. The Export-Import bank boosted certain kinds of overseas lending. ${ }^{96}$ The Small Business Administration backed the early venture capital industry. ${ }^{97}$ As of 2018, the U.S. federal government in 2017 owned $\$ 1.3$ trillion in direct loans, and guaranteed another $\$ 2.6$ trillion; reaching a total of $\$ 3.9$ trillion through hundreds of credit programs. ${ }^{98}$ Numbers are larger if you include currently off-budget entities like Fannie Mae. In times of crisis, government support ramps up. In 2009 a web of guarantees and supports meant that in a worst-case scenario, the U.S. federal government was on the hook for $\$ 23.7$ trillion - the equivalent of $150 \%$ of that year's GDP. ${ }^{99}$

A firmer grounding in the credit programs - both their current operations and their long history - supports the claim that what is new about Block and Hockett's proposals is not the fact of government involvement in credit allocation, but simply the principles that direct it.

\section{A Statement of Principles}

Berle did not assume that the principles of good economic governance were self-evident or self-sustaining. Instead, he articulated essential points, often by listing them. Such lists could be doubly useful for policymakers: first as a kind of compass to guide program design, and second, as a yardstick to gauge results. Fred Block's chapter similarly offers a list of organizational priorities when he explains why financial reform should be nonprofit, 
decentralized, and specialized. Building on this, we ask more generally: What are the core principles of democratic finance itself?

With Berle's work in mind, and taking into consideration the arguments proposed by Hockett and Block anchoring the Democratic Finance agenda, we propose that the principles of democratic finance can be reasonably summarized as consisting of three pillars: allocation, sustainability, and accountability.

(a) Fair allocation. This category concerns the overall distribution of access to credit and financial services. This includes, as McCarthy writes in his chapter, "popular access" to credit and financial services. This category also includes, as Berle emphasizes, the extent to which credit is allocated in accordance with civic priorities.

When it comes to enterprise, fair allocation means that viable public works projects and small businesses can compete with larger firms for capital. When it comes to families, democratic allocation means that financial services and resources are not hoarded by privileged groups, so the poor are left unbanked, or only able to access credit on exploitative terms. Given the legacy of racial discrimination in U.S. credit markets, this will require taking steps to actively redress the legacy of previous lending regimes in redlined and underbanked communities. ${ }^{100}$ When it comes to federal credit, democratic allocation means a reasonably close coupling of risks and profits, so that private firms cannot capture years of profits and then externalize catastrophic losses.

(b) Local and global sustainability. By sustainability, we mean a financial system that promotes short- and long-term stability on the connected levels of the family, the nation, 
and the planet. This presumes a financial system that is internally stable, which is to say, able to avoid spinning off into extreme booms and busts.

For families, sustainable credit is provided through banking terms that are not extractive and exploitative, which is to say via contracts that support the growth, instead of the destruction, of family finances. An example of this can be found with the non-profit Beneficial State Bank, which has shown that low interest rates on auto loans for the working poor can result in default rates of $3-4 \%$, rather than the 30 or $40 \%$ default rates of their competitors. ${ }^{101}$ Over decades, innovations in adjustable rate contracts and riskbased pricing have shifted interest rate and prepayment risks from corporations onto families and small borrowers. A more sustainable financial system will shift more market risks back into the hands of organizations with resources and expertise that enable them to pool and manage such risks.

For the nation, financial sustainability means many things. Berle saw in his capital credit banks a potential counter-cyclical mechanism for dampening the boom and bust cycles in coordination with the Fed. ${ }^{102}$ In an even broader sense, sustainability means anticipating and addressing long term social and environmental needs. This includes, but is not limited to, infrastructure development. This approach is consistent with the call for mission-oriented investment banks proposed in the MacFarlane and Mazzucato chapter.

Internal stability means that the financial system is well regulated, with safeguards against regulatory arbitrage, predatory competition, and rampant speculation. Internal 
stability facilitates, but does not ensure, other facets of stability; a financial system can stay afloat without meeting civic priorities. Robust systems of accountability, which ensure against destabilizing corruption and fraud, reinforce the principle of stability.

(c) Political accountability. This category concerns the process by which decisions are made about financial markets, as Michael McCarthy's chapter explains. For this we ask: Can citizen groups monitor, make claims against, and hold accountable the management of our financial system? Are protections in place to minimize corruption, political patronage, and information asymmetries?

We should rightly celebrate the heyday of the RFC, but also not forget that it spent its last years mired in accusations of kickbacks and insider-dealings, subject to a series of congressional investigations before Eisenhower unwound it in $1954 .{ }^{103}$ We can do better than the RFC when it comes to oversight. Berle provides some ideas here. To encourage a more civic-minded form of banking, for example, he anticipates staffing needs, and suggests recruiting from non-profits, savings, and mutuals.

There are good reasons to be believe that establishing democratic accountability will require special attention to matters of accountability for off-budget and partnership based-programs. As Krippner notes, elected officials may go to great lengths to avoid political responsibility for economic outcomes. ${ }^{104}$ Similarly, in other work Quinn studied federal credit programs and found that government officials repeatedly traded oversight and control for off-budget status. ${ }^{105}$ Time and again, elected officials are not just pulled 
by powerful financial interests into conceding authority and power; they actively push away responsibility for the economy. All of this complicates the matter of oversight and control. As Block notes, we will likely need to adapt structures already in place in quasigovernmental reserve banks, where the boards of governors provide oversight.

Berle provides some guidance here as well. Consider his proposal for the TNEC to use a triple income statement to evaluate the success of an industry. We might take a page from his book, and develop metrics that can be used by third parties to evaluate sociallyresponsible financial soundness.

Whether or not fair allocation, sustainability, and accountability are the best way to summarize the animating principles of democratized finance, the core point here is that there is something to be gained by clearly articulating such guidelines. When it comes down to the nitty gritty work of policy design and implementation, it will be useful to have such statements available to guide the way and measure our progress.

\section{Conclusion}

Berle's proposal to the TNEC was one among many that circulated at the time. Progressives in the late 1930s turned to federal finance to help an economy that awash with unutilized private capital but also deeply troubled. Some proposals narrowly focused on small business lending. Others offered radical reimaginings of the financial system, or conservative countermeasures designed to undermine more dramatic overhauls. Berle's proposal for a 
modern financial toolkit is worthy of consideration, therefore, not because it was some kind isolated call for reform, but rather because it was a vision of American finance steeped in the great debates of its time. Through Berle's memos, we gain insight into a lively era of policy reform, insight that is filtered through the interpretive lens of one the nation's great theorists of democracy and capitalism.

Many points raised by Hockett and Block in their essays find resounding support in Berle's memoranda. Some of the resonances are clear and striking, like debunked myths about the supposed autonomy and efficiency of the private sector; the assertion that governmentgranted privileges are the basis for banking profits; calls for a Public Works Finance Corporation; attention to the needs of small business; and, above all, the insistence that banking serve a larger civic purpose. Berle even offers support for the notion that such a banking system would transition into a new socialist era, although he flatly rejects the desirability of doing so.

Today we can look to Berle not just for specific ideas -- the three part test to evaluate an industry, selective interest rates for public goods, the barring of directors of government banks from political office -- but also for more ideas about how to approach questions of finance. In that spirit, this paper has drawn three principles to guide an ongoing approach to banking reform. First, in the spirit of Berle's pugnaciousness, we call on today's reformers to be bold in our critiques of counter proposals. With this in mind, we reject the encroachment of private equity into the management of public resources. Our second lesson concerns precedents for government action; here we call attention the trillions in loans currently owned or guaranteed via federal credit programs as justification for further reform. The third and final lesson concerns Berle's focus on core principles. In that spirit, we posit three principles of democratic finance: fair allocation, local and global sustainability, and political accountability. 
Above all, Berle's memos reviewed reveal that one of the nation's great thinkers of corporate power and democratic accountability saw banks as public goods that should anticipate and meet a broad range of needs. By that logic, there is no more reason for finance to be subject to wild fluctuations, high profits, and the whims of speculators than our roadways, our energy markets, or our water supply. In fact, there is no need for banks to be profit centers at all when it comes to core social needs. In key domains, interest rates can be set by the needs of the group, not by the tastes of investors. Ultimately, the memos are highly consistent with the notion of banking as a public utility proposed by Hockett and Block at the start of this volume -- and offer strong support for a new and more democratic approach to finance. 
Table 1: Types of New Deal Banking Reforms, 1938 - 1939

\begin{tabular}{|c|c|}
\hline \multicolumn{2}{|l|}{ Targeted Solutions } \\
\hline $\begin{array}{l}\text { Mead } \\
\text { (S. 1482, 1939) }\end{array}$ & Mandated RFC insurance for small business lending to $\$ 100,000$, for 7 years. \\
\hline $\begin{array}{l}\text { Mead } \\
\text { (S. 2343, 1939) }\end{array}$ & RFC guarantees up to $90 \%$ of $\$ 1,000,000$ loans up to 10 years in duration. \\
\hline $\begin{array}{l}\text { Pepper } \\
\text { (S. 3430, 1938) }\end{array}$ & RFC insured loans for small business expansion. (Similar to Mead) \\
\hline $\begin{array}{l}\text { Barkley-Steagall } \\
\text { (S 2759, HR 7120, 1939) }\end{array}$ & $\begin{array}{l}\mathrm{RFC} \text { will fund } \$ 2.7 \text { billion in projects (roads, electrification, railroads) that are off- } \\
\text { books due to self-liquidating nature. }\end{array}$ \\
\hline Hansen Testimony (1939) & Separate budget for capital expenditures. \\
\hline \multicolumn{2}{|l|}{ Radical Reforms } \\
\hline $\begin{array}{l}\text { Pepper } \\
\text { (S. 3630, 1938) }\end{array}$ & Regional Industrial Banks to bypass investment bankers, Fed and RFC. \\
\hline $\begin{array}{l}\text { Long } \\
\text { (S 1743, 1939) }\end{array}$ & $\begin{array}{l}\text { Create a new independent Federal Investment Bank Board and Federal Insurance } \\
\text { Corporation to fund "independent small business." }\end{array}$ \\
\hline $\begin{array}{l}\text { Voorhis } \\
\text { (H.R. 115, 1939) }\end{array}$ & Treasury funded public works at national, state and local levels. \\
\hline $\begin{array}{l}\text { Voorhis } \\
\text { (H.R. 5910, 1939) }\end{array}$ & Regional banks empowered to lend and invest in equity. Primary investor is RFC. \\
\hline $\begin{array}{l}\text { Voorhis } \\
\text { (H.R. 4931, 1939) }\end{array}$ & $\begin{array}{l}\text { Nationalize Fed, allow government to spend without issuing debt, eliminate } \\
\text { fractional reserve banking. }\end{array}$ \\
\hline \multicolumn{2}{|c|}{ Defensive Countermeasures } \\
\hline Fed/Eccles (1939) & Long term loans via new Federal Industrial Loan Corporation \\
\hline
\end{tabular}




\section{ENDNOTES}

${ }^{1}$ We thank the editors and members of the Democratizing Finance Conference (Madison, 2018) for helpful feedback. Please direct communications to Sarah Quinn (slquinn@uw.edu), Associate Professor of Sociology, University of Washington, 211 Savery Hall, Seattle, WA 98195.

2 Adolf A. Berle and Gardiner C. Means, The Modern Corporation and Private Property (New Brunswick, NJ: Transaction Publishers, 2009).

${ }^{3}$ Albin Krebs, "Adolf A. Berle Dies at 76: Lawyer, Economist, Liberal Leader Aided Presidents," New York Times, February 19 1971; Nicholas Lemann, "Institution Man/Adolph Berle and Political Economy," in Blue Sky Meetings, Sponsored By The Center for Law and Economic Studies and The Richard Paul Richman Center for Business, Law, and Public Policy at Columbia University ed. Columbia University (Blue Sky Meetings

2017); Jordan A. Schwarz, Liberal: Adolf A. Berle and the Vision of an American Era (New York: Free Press, 1987).

${ }^{4}$ John McCarten, "Atlas with Ideas," New Yorker 1943.

5 "New Education Is Need. Increased Intelligence and Ability to Think Is Plea," Morning Oregonian, 06-26-1912 1912.

${ }^{6}$ Lemann, "Institution Man."

${ }^{7}$ Ibid.

${ }^{8}$ Elliot A. Rosen, Hoover, Roosevelt, and the Brains Trust (New York: Columbia University Press, 1977), 198.

${ }^{9}$ Lemann, "Institution Man."

${ }^{10}$ For more on Beatrice, see McCarten, "Atlas with Ideas," and Lemann, "Institution Man."

${ }^{11}$ Dalia Tsuk, "From Pluralism to Individualism: Berle and Means and 20th-Century American Legal Thought," Law \& Social Inquiry 30, no. 1 (2005), 179-224.

${ }^{12}$ Arthur M. Schlesinger Jr., The Crisis of the Old Order: 1919-1933, The Age of Roosevelt, Volume I (Kindle Edition: Houghton Mifflin Harcourt, 2003), 3001.

${ }^{13}$ On the publication history of the book, see Robert Hessen, "The Modern Corporation and Private Property: A Reappraisal," The Journal of Law \& Economics 26, no. 2 (1983). Stuart Chase quoted in ibid., 273.

${ }^{14}$ On Charles Beard and John Kenneth Galbraith's take on Berle and Means, see Hessen, "The Modern Corporation and Private Property: A Reappraisal." On John Kenneth Galbraith and Berle, see Lemann, "Institution Man."

${ }^{15}$ On Berle and the two camps, see Lemann, "Institution Man" and Tsuk "From Pluralism to Individualism." For the political infighting in the New Deal, see Ellis Wayne Hawley, The New Deal and the Problem of Monopoly: A Study in Economic Ambivalence (New York: Fordham University Press, 1995).

${ }^{16}$ Berle and Means, The Modern Corporation and Private Property, 8.

${ }^{17}$ For a critique, see Hessen, "The Modern Corporation and Private Property: A Reappraisal." Hessen argues that Berle and Means overstate the difference between property right of the corporation and other forms of co-mingled property, and understate the degree of separate ownership and control in other forms of enterprise. For a rejoinder, see Tsuk, "From Pluralism to Individualism": critiques of Berle and Means often work by limiting the contribution to principal-agency dynamics that flow from the separation of ownership and control, and neglect the broader argument about the accumulation of corporate power. 
${ }^{18}$ As a legal scholar, Delia Tsuk reminds that Berle and Means were advancing a longstanding progressive legal approach, which saw property rights as a social institution secured through state power. Tsuk, "From Pluralism to Individualism"; see also Mark S. Mizruchi, "Berle and Means Revisited: The Governance and Power of Large U.S. Corporations," Theory and Society 33, no. 5 (2004); Elisabeth S. Clemens, "The Problem of the Corporation: Liberalism and the Large Organization," in The Oxford Handbook of Sociology and Organizational Studies:

Classical Foundations, ed. Paul Adler (Oxford University Press, 2009).

${ }^{19}$ Berle quoted in Schlesinger, The Crisis of the Old Order, 3050.

${ }^{20}$ Richard S. Kirkendall, "A. A. Berle, Jr. Student of the Corporation 1917-1932," Business History Review 35, no. 1 (1961); Tsuk.

${ }^{21}$ Raymond Moley, After Seven Years (New York: Harper \& Brothers, 1939), 18.

22 Elliot A. Rosen, Hoover, Roosevelt, and the Brains Trust, 196.

${ }^{23}$ On the commonwealth club talk, see Davis W. Houck, "Fdr's Commonwealth Club Address: Redefining Individualism, Adjudicating Greatness," Rhetoric and Public Affairs 7, no. 3 (2004).

${ }^{24}$ It was Time Magazine that called the Modern Corporation the administration's "economic bible." See Hessen, "The Modern Corporation and Private Property: A Reappraisal," 279.

${ }^{25}$ Moley writes of Berle and other campaign advisors who declined and delayed when offered appointments: "No Elizabeth Bennett ever dodged her Darcy more tantalizingly than some of the men asked to serve by Roosevelt put off their answers." Moley, After Seven Years, 123.

${ }^{26}$ Arthur M. Schlesinger, The Coming of the New Deal, The Age of Roosevelt, Volume II (Boston: Houghton Mifflin, 1988), 432-33.

${ }^{27}$ Krebs, "Adolf A. Berle Dies at 76," 40.

${ }^{28}$ Lemann, "Institution Man," 22.

${ }^{29}$ Moley, After Seven Years, 18.

${ }^{30}$ Schlesinger, The Crisis of the Old Order, 10077

${ }^{31}$ Roosevelt quoted on p. 12-13 of Sebastian Edwards, "Gold, the Brains Trust, and Roosevelt." History of Political Economy 1 March 2017; 49 (1): 1-30. Edwards notes not just the importance of experimentation to FDR, but also the centrality of the Brains Trust in implementing this vision.

32 Adolf A. Berle, Navigating the Rapids, 1st ed. (New York: Harcourt Brace Jovanovich, 1973), 32-59.

33 Ibid., 33.

34 Ibid., 58.

${ }^{35}$ See, for instance, Berle's critique of the proposal from conservative Democrat Bernard Baruch, which focused on corporate bailouts. Baruch saw the role for the government in markets as much more limited beyond times of war than Berle did. For that end, Baruch proposed extensive budget cuts to reduce the federal expenditure. For Berle, this would put individuals at a vulnerable position, and was therefore unacceptable. Ibid., 51.

${ }^{36}$ On Congressional FDIC plans, see Phillips, Ronnie J., The 'Chicago Plan' and New Deal Banking Reform (June 1992), Jerome Levy Economics Institute Working Paper No. 76. Available at SSRN.com

${ }^{37}$ Ibid., 47.

${ }^{38}$ Dodd-Frank Wall Street Reform and Consumer Protection Act, 12 U.S.C. $\S$ IX

${ }^{39}$ S. 1482, S. 2343, 76th Congress (1939).

40 'Draper Suggests Federal Reserve Small Loans Unit', Wall Street Journal (New York, 3 June 1939), 1. 
41 'Reserve Advisory Council Opposes Terms of Mead Bill', Wall Street Journal (New York, 14 June 1939), 2; 'Democrats in Senate Attack Plan to Insure Small Business Loans: Berle's Proposal for New Public Works Finance Group Also Assailed', Wall Street Journal (New York, 31 May 1939), 1.

42 Jesse Jones, To Provide for the Insurance of Loans to Business. (Mead Bill Hearings), 76th Congress, (29 June 1939), 405-427.

${ }^{43}$ James Stuart Olson, Saving Capitalism: The Reconstruction Finance Corporation and the New Deal, 1933-1940 (Princeton: Princeton University Press, 1988).

${ }^{44}$ Elliot Rosen, Roosevelt, The Great Depression and the Economics of Recovery (Charlottesville and London: University of Virginia Press, 2005).

${ }^{45}$ Turner Catledge, "President Pushes Congress to Enact Loan Program Now." New York Times, June 24, 1939;

Self-Liquidating Projects Act of 1939. S. 2759 84th Cong., (1939).

46 "Debt Deceit Seen by Republicans: Lending Program Denounced as Device to Circumvent the 45 Billion Limit." New York Times, July 26, 1939; “An End of Pump-Priming." New York Times, August 6, 1939.

${ }^{47}$ Representative Voorhis (CA). Congressional Record 83, 75th Congress, (11 May 1938), 6706. ${ }^{48}$ Jerry Voorhis, Confessions of a Congressman. First edition. (Garden City, N.Y.: Doubleday, 1947)

${ }^{49}$ S. 3630, 75th Congress, (1938).

${ }^{50}$ To Provide for the Insurance of Loans to Business. (Mead Bill Hearings), S. 3430 75th Cong., (March 7, 1938), 433.

${ }^{51}$ Voorhis, Confessions of a Congressman.

${ }^{52}$ Marriner Eccles, To Provide for the Insurance of Loans to Business. (Mead Bill Hearings), 76th Congress, (5 June 1939), 91. Eccles offered a creative accounting plan that used a surplus from dollar devaluations to ensure that the new corporation would involve "no additional appropriation of public funds and no increase in Budget outlay." Ibid., 93. The corporation was to use $\$ 25$ million of these funds to insure short term loans to small businesses. Remaining funds would be capital for the corporation to either make loans of up to $\$ 1,000,000$ or to insure or rediscount loans made by banks. All together, the plan seems to be a scaled back version of a proposal generated from an earlier committee that included Henry Morgenthau including Jones, Eccles, and Leo Crowley. That earlier plan would create a new industrial loan corporation that would operate completely independent from both the Fed and the RFC, but the Board of Governors rejected the proposal as neither "necessary [n]or desirable," given the existing RFC and Fed programs. Here we see that it was not just Berle who recycled and repurposed the many ideas for reform that circulated at the time. Report of Committee on Credit for Industry to the Interdepartmental Committee on Legislative Matters, Diaries of Henry Morgenthau Jr, April 27, 1933-July 27, 1945, 141:248.

${ }^{53}$ Marriner Eccles, To Provide for the Insurance of Loans to Business. (Mead Bill Hearings), 76th Congress, (5 June 1939), 87-115.

${ }^{54}$ Interdepartmental Banking Committee Meeting, Diaries of Henry Morgenthau Jr, April 27, 1933-July 27, 1945., (13 April 1939), 178:288.

${ }^{55}$ Ibid., 280, 287.

${ }^{56}$ Michael D. Bordo and Joseph G. Haubrich, "Deep Recessions, Fast Recoveries, and Financial Crises: Evidence from the American Record," (2012). c.f. Patricia Waiwood, "Recession of 1937-38," (2013), https://www.federalreservehistory.org/essays/recession_of_1937_38. 
${ }^{57}$ Hawley, The New Deal and the Problem of Monopoly, 408.

${ }^{58}$ Ibid., 419.

59 James Stuart Olson, Saving Capitalism: The Reconstruction Finance Corporation and the New Deal, 1933-1940 (Princeton: Princeton University Press, 1988), 216.

${ }^{60}$ Jesse H. Jones and Edward Angly, Fifty Billion Dollars: My Thirteen Years with the R.F.C. (1932-1945) (New York: Da Capo Press, 1975), 183.

${ }^{61}$ For more on Berle's vision for the state and credit, see Olson, Saving Capitalism, 35-40,8691,118-20. Jones and Angly, Fifty Billion Dollars, 183.

62 Olson, Saving Capitalism, 236.

${ }^{63}$ The First New Deal included a push for a more European-style, corporatist, centralized planning through the National Industrial Recovery Act. That push for European-style planning failed spectacularly, undermined by internal divisions among New Dealers even before the Supreme Court ruled it unconstitutional in 1935. Ira Katznelson, Fear Itself: The New Deal and the Origins of Our Time (New York: Liveright Publishing Corporation, 2013); Hawley The New Deal and the Problem of Monopoly; Schlesinger, The Coming of the New Deal.

${ }^{64}$ Adolf A. Berle, "The Investigation of Business Organization and Practice " (Berle Memorandum of Suggestions to the Temporary National Economic Committee. Kiplinger Washington Agency. Berle Papers. File: "708 TNEC Memorandum: "A Banking System for Capital and Credit" FDR Presidential Library, 1938), 21; "A Banking System for Capital and Capital Credit," (Hyde Park, NY: Berle Papers. File: "708 TNEC Memorandum: "A Banking System for Capital and Credit” FDR Presidential Library, 1939).

${ }^{65}$ Here Berle provides a somber warning against regulatory capture: "The possibility of perversion or recapture of an agency like the Securities and Exchange Commission, for example, gives pause for thought." "The Investigation of Business Organization and Practice," 21.

${ }^{66}$ Ibid., 25.

${ }^{67}$ Berle also notes, in what is perhaps a sly dig at that anti-monopolists, that if one wants to keep business small, simply take away limited liability. Ibid.

${ }^{68}$ Ibid., 6.

69 Ibid., 25.

70 Ibid.

${ }^{71}$ Ibid., 6.

72 Ibid., 10.

${ }^{73}$ Berle, "A Banking System for Capital and Capital Credit."

${ }^{74}$ Ibid., 10.

${ }^{75}$ For a discussion of the economic viability of the work of Moulton and Berle, see Ronnie J.

Phillips, "Bank Credit and Capital Formation: The Heretical View of Harold Moulton and Adolf Berle," Working Paper, Colorado State University (1996), available at SSRN.com.

76 Berle, "A Banking System for Capital and Capital Credit," 7.

77 Ibid., 9.

${ }^{78}$ Ibid., 26.

${ }^{79}$ Ibid., 19.

${ }^{80}$ Temporary National Economic Committee United States, "Investigation of Concentration of Economic Power," (Washington: U. S. Govt. Print. Off., 1940).

${ }^{81}$ Berle, "A Banking System for Capital and Capital Credit," 11.

82 Ibid., 13.

${ }^{83}$ Ibid., 6. 
${ }^{84}$ Ibid., 5.

${ }^{85}$ Ibid.

86 Ibid., 13.

${ }^{87}$ Ibid., 19.

${ }^{88}$ Ibid., 13.

${ }^{89}$ Adolf Berle, Investigation of Concentration of Economic Power (Temporary National

Economic Committee), Res. 113, 76th Congress, (May 23), 3832.

${ }^{90}$ Olson, Saving Capitalism. Berle, "A Banking System for Capital and Capital Credit," 13.

${ }^{91}$ Katznelson, Fear Itself.

92 Ben Protess, Jessica Silver-Greenberg, and Rachel Abrams, "How Private Equity Found Power and Profit in State Capitols," New York Times, July 142016.

93 The White House, "Building up American Infrastructure and American Workers," Fact Sheets (2018), whitehouse.gov.

${ }^{94}$ Chris Edwards, "Encouraging Private Infrastructure Investment," (2013), cato.org.

${ }^{95}$ See https://journals.sagepub.com/toc/pas/0/0

${ }^{96}$ John Zysman, Governments, Markets, and Growth: Financial Systems and the Politics of

Industrial Change, Cornell Studies in Political Economy (Ithaca: Cornell University Press, 1983), 76-77.

${ }^{97}$ Kevin T. Leicht and J. Craig Jenkins, "Political Resources and Direct State Intervention: The Adoption of Public Venture Capital Programs in the American States, 1974-1990," Social Forces 76, no. 4 (1998).

${ }^{98}$ United States Office of Management and Budget, "Analytical Perspectives, Budget of the United States Government, Fiscal Year 2019," (Washington, DC: Government Printing Office, 2018).

${ }^{99}$ Office of the Special Inspector General for the Troubled Asset Relief Program, "Quarterly Report to Congress, October 26, 2016," online at sigtarp.gov.See also Jonathan G. Katz, "Who Benefited from the Bailout?," Minnesota Law Review 95, no. 5 (2011).

${ }^{100}$ On the history and legacy of racial inequality in U.S. credit markets see especially Melvin L. Oliver and Thomas M. Shapiro, Black Wealth, White Wealth: A New Perspective on Racial Inequality, 10th anniversary ed. (New York: Routledge, 2006); Guy Stuart, Discriminating Risk: The U.S. Mortgage Lending Industry in the Twentieth Century (Ithaca: Cornell University Press, 2003); David M. Freund, Colored Property: State Policy and White Racial Politics in Suburban America (Chicago: University of Chicago Press, 2007); Douglas S. Massey and Nancy A.

Denton, American Apartheid: Segregation and the Making of the Underclass (Cambridge, MA: Harvard University Press, 1993); Devah Pager and Hana Shepherd, "The Sociology of Discrimination: Racial Discrimination in Employment, Housing, Credit, and Consumer Markets," Annual Review of Sociology 34, no. 1 (2008).

${ }^{101}$ Karen Kroll, "Kat Taylor: A Beneficial State of Mind," (2016), online at ababankmarketing.com.

102 During slack periods, the capital credit banks could move their lending more towards shortterm and shovel-ready projects. In periods of full employment, lending would be biased towards longer-term development. Berle further proposes dynamically changing interest rates and payment schedules of existing loans during downturns, as a kind of socially managed approach to adjustable rate loans that shifts risks away from families and into the state. By providing flexible payment schedules, the banks could allow individuals, businesses, and budget- 
constrained municipalities to delay payments to maintain employment levels during slumps, which both shortens the slumps and provides the stability to families.

103 "RFC Problems," in Cq Almanac 1951 (Washington: Congressional Quarterly, 1950). "RFC 'Influence' Investigation," in Cq Almanac 1951 (Washington: Congressional Quarterly, 1952). "Boyle, Gabrielson, and R.F.C.," in Cq Almanac 1951 (Washington: Congressional Quarterly, 1952).

${ }^{104}$ Greta Krippner, Capitalizing on Crisis: The Political Origins of the Rise of Finance

(Cambridge, MA: Harvard University Press, 2011).

105 Sarah Quinn, American Bonds: How Credit Markets Shaped a Nation (Princeton: Princeton University Press, 2019). 